\title{
Peningkatan Keterampilan Sosial Peserta Didik SMA Menggunakan Layanan Bimbingan Kelompok Dengan Teknik Diskusi
}

\author{
Laila Maharani, Hardiyansyah Masya, Miftahul Janah \\ Universitas Islam Negeri Raden Intan Lampung \\ lailamaharani@radenintan.ac.id
}

Submitted: 04-04-2018. Revised: 20-05-2018. Accepted: 20-06-2018

\begin{abstract}
The problem in the research is the low social skill of the learners. The problem in this research is "what is group guidance service with effective discussion technique to improve low social skill to class XII student of IPA 2, IPA 5 and IPS 1, IPS 2 SMA Negeri 7 Bandar Lampung academic year 2016/2017?". The purpose of this research is to know that group counseling service with an effective discussion technique to improve low social skill in class XII student of IPA 2, IPA 5 and IPS 1, IPS 2 SMA Negeri 7 Bandar Lampung academic year 2016/2017. The method used in this research is quasi experimental method with pretest-posttest control group design design. Subjects in the study amounted to 20 students class XII IPA and IPS SMA Negeri 7 Bandar Lampung who have low social skills. Data collection techniques in this study using a questionnaire, namely a questionnaire (scale of social skills). The results obtained in this study indicate that social skills can be improved using group counseling services with discussion techniques, it is shown from the results of data analysis using $t$ test, from the scores obtained experiment and control class that is $t_{\text {count }}=2.678>t_{\text {table }}=2.101$ then, Ho is rejected and Ha accepted, which means group guidance services with effective discussion techniques to improve low social skills. Brief conclusions in this study that group guidance services with effective discussion techniques to improve the social skills of student class XII SMA Negeri 7 Bandar Lampung academic year 2016/2017.
\end{abstract} Keywords: guidance; group; discussion; skills; social

\begin{abstract}
Abstrak: Masalah dalam penelitian adalah keterampilan sosial peserta didik rendah. Permasalahan dalam penelitian ini adalah "apakah layanan bimbingan kelompok dengan teknik diskusi efektif untuk meningkatkan keterampilan sosial yang rendah pada peserta didik kelas XII IPA 2, IPA 5 dan IPS 1, IPS 2 SMA Negeri 7 Bandar Lampung tahun ajaran 2016/2017?". Tujuan dari penelitian ini adalah untuk mengetahui bahwa layanan bimbingan kelompok dengan teknik diskusi ektif untuk meningkatkan keterampilan sosial yang rendah pada peserta didik kelas XII IPA 2, IPA 5 dan IPS 1, IPS 2 SMA Negeri 7 Bandar Lampung tahun ajaran 2016/2017. Metode yang digunakan dalam penelitian ini adalah metode quasi eksperimen dengan desain pretest-posttest control group design. Subjek dalam penelitian berjumlah 20 peserta didik kelas XII IPA dan IPS SMA Negeri 7 Bandar Lampung yang memiliki keterampilan sosial rendah. Teknik pengumpulan data dalam penelitian ini menggunakan angket, yaitu angket (skala tentang keterampilan sosial). Hasil yang diperoleh dalam penelitian ini menunjukkan bahwa keterampilan sosial dapat ditingkatkan menggunakan layanan bimbingan kelompok dengan teknik diskusi, hal ini ditunjukkan dari hasil analisis data dengan menggunakan t-test, dari skor yang diperoleh kelas eksperimen dan kontrol yaitu $\mathrm{t}_{\text {hitung }}=2,678>\mathrm{t}_{\text {tabel }}=2,101$ maka, Ho ditolak dan Ha diterima, yang artinya layanan bimbingan kelompok dengan teknik diskusi efektif untuk meningkatkan keterampilan sosial yang rendah. Secara singkat kesimpulan dalam penelitian ini bahwa layanan bimbingan kelompok dengan teknik diskusi efektif untuk meningkatkan keterampilan sosial peserta didik kelas XII SMA Negeri 7 Bandar Lampung tahun ajaran 2016/2017.
\end{abstract}

Kata Kunci : bimbingan; kelompok; diskusi; keterampilan; sosial

\section{Pendahuluan}

Secara hakiki manusia adalah makhluk sosial yang selalu hidup berdampingan dengan manusia lain. Sebagai makhluk sosial manusia tidak dapat menjalin hubungan sendiri, selalu menjalin hubungan dengan orang lain, mencoba untuk mengenali dan memahami kebutuhan satu sama lain, membentuk interaksi, serta berusaha mempertahankan interaksi yang telah 
dibangun. Ketika manusia melakukan interaksi dengan orang lain, maka secara langsung manusia akan melakukan hubungan interpersonal. (Sarwono \& Meinarno, 2009). Saat interaksi berlangsung, terdapat jalinan komunikasi, untuk menyampaikan pesan, baik komunikasi verbal maupun komunikasi nonverbal. Kemampuan diri untuk menyesuaikan terhadap lingkungan sosial juga mempengaruhi bagaimana orang lain mampu menerima diri kita dalam kelompok sosial tersebut. Kehidupan sosial memang menuntut manusia untuk dapat menyesuaikan diri dan bergabung dengan lingkungan yang mungkin tidak mendukung, untuk itu sangat dibutuhkan keterampilan sosial yang baik untuk dapat mengikuti kehidupan sosial yang semakin berkembang.

Keterampilan sosial sendiri adalah kemampuan individu untuk berkomunikasi efektif dengan orang lain baik secara verbal maupun nonverbal sesuai dengan situasi dan kondisi yang ada pada saat itu, dimana keterampilan ini merupakan perilaku yang dipelajari. Peserta didik dengan keterampilan sosial akan mampu mengungkapkan perasaan baik positif maupun negatif dalam hubungan interpersonal, tanpa harus melukai orang lain. (Yusranadam, 2013) Keterampilan sosial merupakan keterampilan yang timbul akibat hubungan antar manusia dengan manusia lain yang saling membutuhkan. Seiring dengan berjalannya kehidupan sosial, masyarakat menuntut manusia untuk memiliki keterampilan sosial yang semakin baik pula sesuai dengan usia seseorang dalam lingkungan sosial. Keterampilan sosial harus berkembang sesuai dengan usia manusia.

Perkembangan keterampilan sosial merupakan pencapaian kematangan dalam hubungan sosial. Dapat juga diartikan sebagai proses belajar untuk menyesuaikan diri terhadap norma-norma kelompok sosial, moral, tradisi, meleburkan diri menjadi suatu kesatuan yang saling berkomunikasi dan bekerjasama. Seorang manusia dilahirkan belum memiliki keterampilan sosial. Belum memiliki kemampuan untuk bergaul dengan orang lain. Pencapaian keterampilan sosial yang baik ditandai dengan kematangan sosial seorang manusia. Untuk mencapai kematangan sosial, seorang manusia harus belajar tentang cara-cara menyesuaikan diri dengan orang lain. Kemampuan ini diperoleh melalui berbagai kesempatan atau pengalaman bergaul dengan orang-orang di lingkungannya, baik orang tua, saudara, teman sebaya, dan orang dewasa lainnya.

Lingkungan orang tua, dan keluarga akan sangat menentukan bagi pembentukkan moral, jika peserta didik memiliki jiwa sosial atau keterampilan sosial yang baik maka peserta didik dapat memahami karakter dari teman-temannya, dan hal tersebut akan memudahkan bagi guru untuk membangun aspek kedua dari komunitas moral, yakni peserta didik saling menghormati, mendukung, dan peduli kepada satu sama lain. (Yusranadam, 2013) Dari manfaat yang telah diuraikan, maka dari itu keterampilan sosial memiliki peranan penting dalam kehidupan sosial peserta didik khususnya di lingkungan sekolah. Menurut Zainun Mu'tadin, keterampilan sosial dan kemampuan penyesuaian diri menjadi semakin penting dan krusial manakala peserta didik telah menginjak masa remaja. Hal ini disebabkan karena pada masa remaja peserta didik sudah memasuki dunia pergaulan yang lebih luas dimana pengaruh teman dan lingkungan sosial akan sangat menentukan.

Semakin pentingnya keterampilan sosial pada masa remaja pun membuat peserta didik berlomba-lomba untuk selalu belajar dan membenahi diri. Namun, ada saja peserta didik yang mengalami kegagalan dalam menguasai keterampilan sosial. Kegagalan peserta didik dalam menguasai keterampilan sosial akan menyebabkan rendah diri, dikucilkan dari pergaulan, cenderung berperilaku yang kurang normatif (misalnya asosial atau anti sosial), dan bahkan dalam perkembangan yang lebih ekstrim bisa menyebabkan terjadinya gangguan jiwa, kenakalan remaja, tindakan kriminal, tindakan kekerasan, dan lain sebagainya. Kegagalan ini dinamakan prestasi diri yang negatif atau gagal. (Mustofa, Pendidikan Kewarganegaraan SMP, Mustofa, “ Pendidikan Kewarganegaraan SMP” (On-line), tersedia di http://mustofasmp2/pentingnya-keterampilan-sosial/ (19 April 2016).) 
Melihat dampak dari ketidakcakapan peserta didik dalam berketerampilan sosial, maka sangat jelas bahwa keterampilan sosial memang harus dimiliki oleh peserta didik. Peserta didik dengan usia 15 sampai 18 tahun, masuk kedalam perkembangan adolesen. Perkembangan pada masa adolesen (15-20 tahun), orang mulai mengembangkan pengertian tentang kenyataan hidup serta mulai memikirkan pola tingkah laku yang bernilai moral. Manusia juga mulai belajar memikirkan kepentingan sosial serta kepentingan pribadinya. (Dalyono, 2012)

Salah satu tugas perkembangan peserta didik pada usia remaja yang berada dalam fase perkembangan masa remaja adalah memiliki keterampilan sosial (social skill) untuk dapat menyesuaikan diri dengan kehidupan sehari-hari. Keterampilan sosial tersebut meliputi: (1) kemampuan berkomunikasi; (2) menjalin hubungan dengan orang lain; (3) menghargai diri sendiri dan orang lain; (4) mendengarkan pendapat atau keluhan orang lain; (5) memberi atau menerima feedback (umpan balik); (6) memberi atau menerima kritik; dan (7) bertindak sesuai norma dan aturan yang berlaku. (Mustofa, Pendidikan Kewarganegaraan SMP)

\section{Metode Penelitian}

Pendekatan penelitian yang akan digunakan dalam penelitian ini yaitu pendekatan kuantitatif, dan jenis penelitian adalah penelitian quasi eksperimen, karena untuk mengetahui bagaimana peningkatan keterampilan sosial peserta didik menggunakan layanan bimbingan kelompok dengan teknik diskusi, dan data-data yang didapat berupa data tertulis dan lisan. Sebagaimana definisi metode penelitian kuantitatif yaitu metode penelitian yang berlandaskan pada filsafat positivism, digunakan untuk meneliti pada populasi atau sampel tertentu, pengumpulan data menggunakan instrumen penelitian, analisis data bersifat kuantitatif/statistik, dengan tujuan untuk menguji hipotesis yang telah ditetapkan(Sugiyono, 2010). Jenis desain yang digunakan dalam penelitian ini adalah Pre-test and Post-test Control Group Design.

Pada penelitian ini populasi yang diambil adalah kelas XII IPA 2, IPA 5 dan XII IPS 1, IPS 2 SMA Negeri 7 Bandar Lampung dengan jumlah 120 peserta didik. Dalam hal ini peserta didik diberikan skala keterampilan sosial yang berupa angket pernyataan pada peserta didik kelas XII IPA 2, IPA 5 dan XII IPS 1, IPS 2 yang kemudian diperoleh jumlah peserta didik yang memiliki keterampilan sosial rendah. Skala keterampilan sosial berfungsi menjaring peserta didik yang memiliki keterampilan sosial rendah dengan pretest untuk mendapatkan sampel penelitian dengan kriteria yang telah ditentukan kemudian akan diberikan layanan bimbingan kelompok dengan teknik diskusi sebagai treatmen.

\section{Hasil Dan Pembahasan}

Pelaksanaan penelitian ini menggunakan layanan bimbingan kelompok dengan teknik diskusi sebagai teknik dalam bimbingan dan konseling dilakukan pada anggota kelompok eksperimen. Kegiatan tersebut dilaksanakan di ruang BK SMA Negeri 7 Bandar Lampung. Pretest diberikan pada hari kepada seluruh peserta didik kelas XII IPS 1, XII IPS 2, XII IPA 2, dan XII IPA 5 SMA Negeri 7 Bandar Lampung yang tergabung pada kelompok eksperimen dan kelompok kontrol dalam waktu yang bersamaan.

Pada tahap ini bertujuan untuk membina hubungan baik diawal pertemuan dengan peserta didik, serta memberikan pengarahan tentang penelitian yang akan dilakukan tentang efektivitas layanan bimbingan kelompok dengan teknik diskusi serta menggali informasi terkait keterampilan sosial peserta didik dalam kehidupan sehari-hari. Hasil pelaksanaan pretest dapat dikatakan cukup lancar hal ini dapat dilihat dari seluruh peserta didik yang 
bersedia untuk mengisi instrumen penelitian yang dapat terisi sesuai dengan petunjuk pengisian. Kegiatan pretest dilaksanakan selama \pm 30 menit.

Kelompok eksperimen merupakan kelompok yang akan diberikan perlakuan menggunakan bimbingan kelompok dengan teknik diskusi sebagai teknik dalam bimbingan konseling sedangkan kelompok kontrol sama halnya dengan kelompok eksperimen, kelompok kontrol juga diberikan perlakuan dengan layanan bimbingan kelompok dengan teknik diskusi, namun perbedaanya adalah kelompok kontrol memiliki nilai yang lebih lebih tinggi dari kelompok eksperimen. Pelaksanaan bimbingan kelompok tersebut dilaksanakan selama tiga minggu dengan topik pembahasan yang berbeda pada tiap pertemuannya.

Efektifitas teknik diskusi sebagai teknik dalam bimbingan dan konseling dalam meningkatkan keterampilan sosial peserta didik dapat dilihat dari perbandingan hasil gain score pada kelompok eksperimen dan kelompok kontrol sebelum dan sesudah pelaksanaan layanan bimbingan kelompok dengan teknik diskusi. Sebelum dilakukan perbandingan gain score, terlebih dahulu dilakukan uji t untuk mengetahui pengaruh layanan bimbingan kelompok dengan teknik diskusi sebagai teknik dalam bimbingan dan konseling dalam meningkatkan keterampilan sosial peserta didik.

Berdasarkan hasil penelitian yang telah dilakukan menunjukkan bahwa keterampilan sosial peserta didik di SMA Negeri 7 Bandar Lampung, kelas XII IPA 2 dan XII IPA 5 berada pada kategori rendah. Peserta didik yang keterampilan sosialnya rendah kurang memiliki kepercayaan terhadap lingkungan sekitarnya, hal ini yang menyebabkan peserta didik sering menutup diri mereka dan cenderung asyik dengan diri sendiri tanpa memperhatikan orang lain dan individualis. Tanpa keterampilan sosial, peserta didik memiliki resiko kegagalan ataupun kurang optimal dalam mengerjakan tugas-tugasnya sebagai makhluk sosial. Berbanding terbalik dengan peserta didik kelas XII IPS 1 dan XII IPS 2, yang memiliki keterampilan sosial tinggi. Mereka cenderung kompak, mempunyai rasa solidaritas yang ringgi, dan ramah terhadap sesamanya.

Ketika peserta didik tidak memiliki keterampilan sosial yang baik maka akan muncul perasaan malu, mider, dan sungkan dalam menjalin suatu pembicaraan. Hal tersebut akan dimanifestasikan dalam sebuah tingkah laku yang kurang wajar atau menyimpang, seperti rendah diri, terisolir, bahkan prestasi belajar yang rendah. Hal ini sesuai dengan pendapat Mustofa dalam penelitiannya menyatakan bahwa tidak semua peserta didik memiliki keterampilan sosial yang tinggi, sikap individualis, perasaan minder, malu, dan sungkan menjadi kendala bagi peserta didik dalam menjalani proses belajarnya di sekolah maupun di lingkungannya. Peserta didik yang selalu beranggapan bahwa dirinyalah yang paling benar, atau dirinya yang paling buruk, merasa dirinya tidak berharga, merupakan gambaran dari peserta didik yang mempunyai masalah keterampilan sosial rendah. Hal ini dapat dimanifestasikan dalam bentuk tingkah laku yang kurang wajar atau menyimpang, seperti rendah diri, terisolir, bahkan prestasi belajar yang rendah.

Tabel 1. Deskripsi Data Pretest, Posttest, Gain Score

\begin{tabular}{cccccccc}
\hline \multicolumn{3}{c}{ Kelompok Eksperimen } & \multicolumn{4}{c}{ Kelompok Kontrol } \\
\hline No & Pretest & Posttest & Score & No & Pretest & Posttest & Score \\
$\mathbf{1}$ & 80 & 96 & 16 & 1 & 100 & 106 & 6 \\
$\mathbf{2}$ & 78 & 88 & 10 & 2 & 106 & 110 & 4 \\
$\mathbf{3}$ & 79 & 89 & 10 & 3 & 106 & 110 & 4 \\
$\mathbf{4}$ & 80 & 90 & 10 & 4 & 106 & 111 & 5 \\
$\mathbf{5}$ & 80 & 89 & 9 & 5 & 97 & 105 & 8 \\
$\mathbf{6}$ & 80 & 105 & 25 & 6 & 96 & 104 & 8 \\
$\mathbf{7}$ & 79 & 89 & 10 & 7 & 97 & 106 & 9 \\
$\mathbf{8}$ & 80 & 102 & 22 & 8 & 87 & 100 & 13 \\
$\mathbf{9}$ & 80 & 105 & 25 & 9 & 99 & 106 & 7 \\
\hline
\end{tabular}




\begin{tabular}{cccccccc}
\hline $\mathbf{1 0}$ & 80 & 104 & 24 & 10 & 95 & 104 & 9 \\
$\sum_{\mathbf{R a}}$ & $\mathbf{7 9 6}$ & $\mathbf{9 5 7}$ & $\mathbf{1 6 1}$ & $\sum$ & $\mathbf{9 8 9}$ & $\mathbf{1 0 6 2}$ & $\mathbf{7 3}$ \\
$\mathbf{7 9 , 6}$ & $\mathbf{9 5 , 7}$ & $\mathbf{1 6 , 1}$ & $\mathbf{R a}$ & $\mathbf{9 8 , 9}$ & $\mathbf{1 0 6 , 2}$ & $\mathbf{7 , 3}$ \\
\hline \multicolumn{7}{c}{ Sumber : Data Pribadi }
\end{tabular}

Berdasarkan hasil penghitungan rata-rata pretest dan posttest pada kelompok eksperimen dan kelompok kontrol sama-sama mengalami kenaikan, pada kelompok eksperimen $(79,6 \leq 95,7)$ dan pada kelompok kontrol $(98,9 \leq 106,2)$. Namun, meskipun kedua kelompok sama-sama mengalami peningkatan, tetapi nilai rata-rata kelompok eksperimen lebih tinggi dari kelompok kontrol, hal ini dapat dilihat dari hasil score kelompok eksperimen lebih besar dari pada kelompok kontol (161 $\geq 73)$. Maka dapat disimpulkan bahwa setelah pemberian layanan bimbingan kelompok dengan teknik diskusi peserta didik mengalami peningkatan keterampilan social dapat dilihat pada gambar 1 .

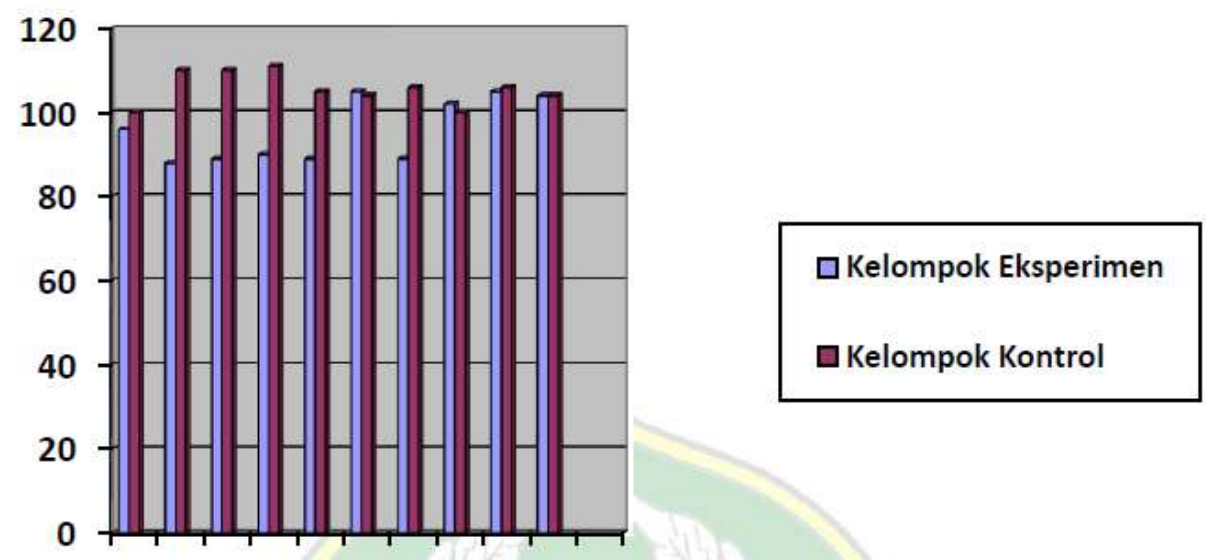

$\begin{array}{lllllllllll}1 & 2 & 3 & 4 & 5 & 6 & 7 & 8 & 9 & 10\end{array}$

Gambar 1. Grafik Peningkatan Keterampilan Sosial Kelompok Eksperimen dan Kelompok Kontrol

Berdasarkan hasil penelitian yang telah dilakukan menunjukkan bahwa keterampilan sosial peserta didik di SMA Negeri 7 Bandar Lampung, kelas XII IPA 2 dan XII IPA 5 berada pada kategori rendah. Peserta didik yang keterampilan sosialnya rendah kurang memiliki kepercayaan terhadap lingkungan sekitarnya, hal ini yang menyebabkan peserta didik sering menutup diri mereka dan cenderung asyik dengan diri sendiri tanpa memperhatikan orang lain dan individualis. Tanpa keterampilan sosial, peserta didik memiliki resiko kegagalan ataupun kurang optimal dalam mengerjakan tugas-tugasnya sebagai makhluk sosial. Berbanding terbalik dengan peserta didik kelas XII IPS 1 dan XII IPS 2, yang memiliki keterampilan sosial tinggi. Mereka cenderung kompak, mempunyai rasa solidaritas yang ringgi, dan ramah terhadap sesamanya.

Ketika peserta didik tidak memiliki keterampilan sosial yang baik maka akan muncul perasaan malu, mider, dan sungkan dalam menjalin suatu pembicaraan. Hal tersebut akan dimanifestasikan dalam sebuah tingkah laku yang kurang wajar atau menyimpang, seperti rendah diri, terisolir, bahkan prestasi belajar yang rendah. Hal ini sesuai dengan pendapat Mustofa dalam penelitiannya menyatakan bahwa tidak semua peserta didik memilikiketerampilan sosial yang tinggi, sikap individualis, perasaan minder, malu, dan sungkan menjadi kendala bagi peserta didik dalam menjalani proses belajarnya di sekolah maupun di lingkungannya. Peserta didik yang selalu beranggapan bahwa dirinyalah yang 
paling benar, atau dirinya yang paling buruk, merasa dirinya tidak berharga, merupakan gambaran dari peserta didik yang mempunyai masalah keterampilan sosial rendah. Hal ini dapat dimanifestasikan dalam bentuk tingkah laku yang kurang wajar atau menyimpang, seperti rendah diri, terisolir, bahkan prestasi belajar yang rendah. Oleh karena itu dalam penelitian ini peneliti ingin membantu peserta didik untuk meningkatkan keterampilan sosial terutama pada kelas yang berada pada kategori rendah dengan mengunakan teknik diskusi sebagai teknik dalam bimbingan dan konseling, agar peserta didik dapat memiliki keterampilan sosial yang akan berpengaruh pada perkembangan keterampilan dan kemandirian serta membuat peserta didik dapat bersosialisasi dengan baik (pandai bergaul).

Berdasarkan hasil analisis data menunjukkan bahwa terdapat perbedaan setiap indikator antara kelompok eksperimen yang mempunyai keterampilan sosial rendah dengan kelompok kontrol yang memiliki keterampilan sosial yang tinggi. Perbedaan setiap indikator tersebut adalah sebagai berikut:

\section{a. Indikator Peer Relationship}

Berdasarkan penyebaran angket keterampilan sosial pada kelompok eksperimen dan kelompok kontrol, keduanya mengalami peningkatan. Kelompok eksperimen meningkat dari $65,68 \%$ menjadi $73,86 \%$. Sedangkan pada kelompok kontrol meningkat dari 76,59\% menjadi $80 \%$. Namun, kelompok kontrol lebih besar peningkatannya dibandingkan dengan kelompok eksperimen $(80 \%>73,86 \%)$.

Maka dapat dikatakan bahwa layanan bimbingan kelompok dengan teknik diskusi lebih efektif untuk meningkatkan keterampilan sosial peserta didik. Pada indikator ini, peserta didik sudah terlihat cakap dalam keterampilan sosial, seperti memberanikan diri untuk bertanya kepada guru ketika ada mata pelajaran yang tidak dimengerti, berani menyampaikan pendapat tanpa melukai hati orang lain, mulai menyukai belajar kelompok, dan mulai berani untuk mengerjakan soal didepankelas. Hal ini sesuai dengan pendapat Syaifullah dalam Dewi tentang ciri-ciri pribadi seseorang yang memiliki sikap percaya diri yang masuk pada ciri-ciri keterampilan sosial diantaranya bisa menghargai usahanya sendiri, dan berani menyampaikan pendapat. 50

\section{b. Indikator Manajemen Diri}

Berdasarkan penyebaran angket keterampilan sosial pada kelompok eksperimen dan kelompok kontrol, keduanya mengalami peningkatan. Kelompok eksperimen meningkat dari $62,86 \%$ menjadi $76,79 \%$. Sedangkan pada kelompok kontrol meningkat dari 78,21\% menjadi $78,5 \%$. Namun, kelompok kontrol lebih besar peningkatannya dibandingkan dengan kelompok eksperimen $(78,5 \%>76,79 \%)$. Maka dapat dikatakan bahwa layanan bimbingan kelompok dengan teknik diskusi efektif untuk meningkatkan keterampilan sosial peserta didik dibandingkan dengan bimbingan kelompok tanpa teknik diskusi. Pada indikator ini, peserta didik sudah terlihat mampu untuk menjalankan tugas dan perannya sebagai makhluk sosial, dan memiliki keyakinan dalam belajar. Hal ini sesuai dengan pendapat Enung Fatimah tentang beberapa ciri atau karakteristik individu yang memiliki sikap keterampilan sosial yang berkaitan dengan percaya diri yaitu percaya akan kompetensi/kemampuandiri, hingga tidak membutuhkan pujian, pengakuan, penerimaan, ataupun hormat dari orang lain. Tidak mudah menyerah serta tidak tergantung mengharapkan bantuan orang lain.51

c. Indikator Kesuksesan Akademik

Berdasarkan penyebaran angket keterampilan sosial pada kelompok eksperimen dan kelompok kontrol, keduanya mengalami peningkatan. Kelompok eksperimen meningkat dari $61 \%$ menjadi $71 \%$. Sedangkan pada kelompok kontrol meningkat dari $77,5 \%$ menjadi $78 \%$. 
Namun, kelompok kontrol lebih besar peningkatannya dibandingkan dengan kelompok eksperimen $(78 \%>71 \%)$. Maka dapat dikatakan bahwa layanan bimbingan kelompok dengan teknik diskusi efektif untuk meningkatkan keterampilan sosial peserta didik dibandingkan dengan bimbingan kelompok tanpa teknik diskusi. Pada indikator ini, peserta didik sudah terlihat mampu untuk menjalankan tugas dan perannya sebagai makhluk sosial, belajar secara mandiri, dan memiliki keyakinan dalam belajar.

d. Indikator Kepatuhan

Berdasarkan penyebaran angket keterampilan sosial pada kelompok eksperimen dan kelompok kontrol, keduanya mengalami peningkatan. Kelompok eksperimen meningkat dari $69,38 \%$ menjadi $76,88 \%$. Sedangkan pada kelompok kontrol tidak meningkat dari $82,5 \%$ menjadi $82,5 \%$. Namun, kelompok kontrol lebih besar peningkatannya dibandingkan dengan kelompok eksperimen $(82,5 \%>76,88 \%)$. Maka dapat dikatakan bahwa layanan bimbingan kelompok dengan teknik diskusi efektif untuk meningkatkan keterampilan sosial peserta didik dibandingkan dengan bimbingan kelompok tanpa teknik diskusi. Pada indikator ini, peserta didik sudah terlihat mampu untuk menjalankan tugas dan perannya sebagai makhluk sosial, mulai mendisplinkan diri sendiri dalam kegiatan sehari-hari, dan memiliki keyakinan dalam belajar.

\section{e. Indikator Asertif}

Berdasarkan penyebaran angket keterampilan sosial pada kelompok eksperimen dan kelompok kontrol, keduanya mengalami peningkatan. Kelompok eksperimen meningkat dari $56 \%$ menjadi $72 \%$. Sedangkan pada kelompok kontrol tidak meningkat dari $78 \%$ menjadi $78 \%$. Namun, kelompok kontrol lebih besar peningkatannya dibandingkan dengan kelompok eksperimen (78\%>72\%). Maka dapat dikatakan bahwa layanan bimbingan kelompok dengan teknik diskusi efektif untuk meningkatkan keterampilan sosial peserta didik dibandingkan dengan bimbingan kelompok tanpa teknik diskusi. Pada indikator ini, peserta didik sudah terlihat mampu untuk menjalankan tugas dan perannya sebagai makhluk sosial, dan memiliki keyakinan dalam belajar.

\section{Simpulan dan Saran}

Berdasarkan hasil penelitian ditunjukkan dengan analisis data dan pembahasan maka peneliti dapat menyimpulkan bahwa layanan bimbingan kelompok dengan teknik diskusi efektif untuk meningkatkan keterampilan sosial peserta didik kelas XII SMA Negeri 7 Bandar Lampung tahun ajaran 2016/2017. Hal ini terbukti dari hasil perhitungan rata-rata skor keterampilan sosial pada kelompok eksperimen dan kontrol sebelum mengikuti layanan bimbingan kelompok dengan teknik diskusi adalah 79,6 dan 95,7 setelah diberikan layanan bimbingan kelompok terjadi peningkatan pada kelompok eksperimen dan kelompok kontrol menigkat dari 98,9 menjadi 106,2.

Dari hasil uji t menggunkan program SPSS versi 16, ttabel statistik alfa 0,05. Kemudian thitung dibandingkan dengan ttabel dengan ketentuan thitung lebih besar dari ttabel $(2,678 \geq 2,101)$ dengan demikian keterampilan sosial peseta didik mengalami perubahan setelah diberikan layanan bimbingan kelompok dengan teknik diskusi. Jadi ini menunjukkan bahwa Ho ditolak dan Ha diterima, maka dapat disimpulkan bahwa terdapat pengaruh layanan bimbingan kelompok dengan teknik diskusi dalam meningkatkan keterampilan sosial peserta didik kelas XII IPA dan XII IPS.

Secara keseluruhan penelitian ini menghasilkan kesimpulan bahwa layanan bimbingan kelompok dengan teknik diskusi efektif untuk meningkatkan keterampilan sosial peserta didik. Pengaruh layanan bimbingan kelompok dengan teknik diskusi ini ditandai dengan adanya peningkatan keterampilan sosial peserta didik. Perubahan yang terjadi adalah peserta didik memberanikan diri untuk menyampaikan pendapat tanpa melukai hati orang lain, mulai 
menyukai belajar kelompok, kompak dengan teman sekelas, peserta didik juga mampu untuk menjalankan tugas dan perannya sebagai makhluk sosial, dan memiliki keyakinan dalam belajar. Lalu peserta didik sudah mampu belajar secara mandiri, mendisiplinkan diri sendiri, dan mampu menjalankan tugas dan perannya sebagai makhluk sosial. Hal ini dapat dilihat dari perbedaan dan perbandingan antara hasil preetest dan posttes.

\section{Daftar Pustaka}

Dalyono, M. 2010. Psikologi Pendidikan, Jakarta: Rineka Cipta.

Mustofa. Pendidikan Kewarganegaraan SMP. (On-line), tersedia di: http://mustofasmp2/pentingnya-keterampilan-sosial/ (19 April 2016).

Sarwono, Sarlito. W \& Meinarno, Eko. A. 2009. Psikologi Sosial, Depok: Salemba Humanika

Sugiyono. 2010. Metode Penelitian Pendidikan (Pendekatan Kuantitatif, Kualitatif, dan R \& $D)$, Bandung: Alfabeta.

Yusranadam, 2013. Meningkatkan keterampilan sosial melalui bimbingan kelompok teknik diskusi pada siswa. (jurnal). Ilmu Pendidikan Jurusan Bimbingan Dan Konseling Universitas Negeri Gorontalo. 